\title{
KONSERVASI MATA AIR BERBASIS MASYARAKAT DI UNIT FISIOGRAFI PEGUNUNGAN BATURAGUNG, LEDOK WONOSARI DAN PERBUKITAN KARST GUNUNG SEWU, KABUPATEN GUNUNGKIDUL
}

\author{
Sudarmadji \\ Pengelola Program Studi Ilmu Lingkungan Sekolah Pascasarjana \\ Universitas Gadjah Mada \\ paksudarmadji@yahoo.com \\ Slamet Suprayogi, M. Widyastuti, dan Rika Harini \\ slametsuprayogi@yahoo.com,m.widyastuti@geo.ugm.ac.id, dan \\ Harini_rika@yahoo.co.id \\ Fakultas Geografi Universitas Gadjah Mada
}

\begin{abstract}
Spring is as one of the water resources potential that can not be ignored. Gunungkidul district has three physiographic units: Baturagung Hills, Wonosari Basin and Gunung Sewu Karst Hills. All of them affect the distribution of springs in the Gunungkidul Regency. On the other hand, physiography will affect the community adaptation to the environment. It will contribute to the springs conservation effort. The purposes of this research are: 1) to identify the characteristics of springs, 2) to analyze the community participation in conserving the springs as basic information to develop spring conservation models. To identify the socio-economic characteristics and the springs characteristics in the research areas use a survey method. Unit sampling and analysis is done purposively based on three zones: Baturagung Hills, Wonosari Basin and Gunung Sewu Karst Hills. Socioeconomic survey was done by sampling on the 90 respondents, divided into 3 zones through direct interviews using quetionare. Quantitative descriptive analysis was performed through statistical tests. The results show that the quality of spring water in all physiographic zones meet to the water quality standard, except those for colli bacteria. The discharge of karst springs in the hills of Gunung Sewu greater than the discharge of the two other zones. The springs distribution is more in Wonosari Basin and Karst Hills of Gunung Sewu than Baturagung Hills. The level of the community participation in springs conservation is mostly done in groups through user spring groups. Generally, socio-economic factors affect to the level of participation in prevention of springs damage.
\end{abstract}

Key words : conservation, spring, community participation

\footnotetext{
ABSTRAK

Mata air sebagai salah satu sumberdaya air mempunyai potensi yang tidak dapat diabaikan. Kabupaten Gunungkidul mempunyai tiga satuan fisiografi: Perbukitan Baturagung, Ledok Wonosari dan Pegunungan Karst Gunung Sewu. Ketiganya berpengaruh terhadap distribusi mata air. Di sisi lain, fisiografi akan
} 


\section{SUDARMADJI, SLAMET SUPRAYOGI, M.WIDYASTUTI, RIKA HARINI \& KONSERVASI MATA AIR BERBASIS MASYARAKAT DI UNIT FISIOGRAFI PEGUNUNGAN BATURAGUNG, ...}

berpengaruh terhadap adaptasi masyarakat dengan lingkungan. Hal itu akan memberikan sumbang sih yang sangat besar dalam upaya konservasi mata air. Tujuan penelitian ini adalah (1) mengidentifikasi karakteristik mata air; (2) mengetahui partisipasi masyarakat dalam upaya pelestarian mata air sebagai informasi awal dalam menyusun model konservasi mata air berbasis masyarakat. Untuk mengidentifikasi karakteristik mata air dan sosial ekonomi daerah penelitian menggunakan metode survei. Unit sampling dan analisis dilakukan secara purposive mendasarkan pada tiga zona; Perbukitan Baturagung, Ledok Wonosari, dan Perbukitan Karst Gunung Sewu. Survei sosial ekonomi dengan cara sampling pada 90 responden yang terbagi ke dalam tiga zona melalui wawancara langsung dan depth interview. Analisis dilakukan secara deskriptif kuantitatif melalui uji statistik yang disajikan dalam bentuk tabel, grafik, dan peta. Hasil penelitian menunjukkan bahwa kualitas air mata air di semua zona fisiografi termasuk dalam kategori baik, kecuali bakteri coli. Secara kuantitas, debit mata air di Perbukitan Karst Gunung Sewu lebih besar dibandingkan dengan kedua zona lainnya. Distibusi mata air lebih banyak di Ledok Wonosari dan Perbukitan Karst Gunung Sewu. Tingkat partisipasi masyarakat dalam pelestarian mata air lebih banyak dilakukan secara berkelompok melalui kelompok pengguna mata air. Faktor sosial ekonomi masyarakat secara umum berpengaruh terhadap tingkat partisipasi pada pencegahan kerusakan mata air.

Kata kunci : konservasi, mata air, partisipasi masyarakat

\section{PENGANTAR}

Air sebagai sumberdaya untuk memenuhi kebutuhan manusia merupakan sesuatu yang mutlak. Kerawananataukekritisan pemenuhan sumberdaya air telah terjadi tidak hanya dipandang dari ketimpangan antara jumlah ketersediaan dan kebutuhan (kuantitas) saja, tetapi kerawanan juga terjadi pada sebaran (distribusi) secara temporal maupun spasial. Mataairsebagaisalahsatusumberdayaairtanah yang mucul di permukaan menjadi andalan masyarakat dalam pemenuhan kebutuhan air. Keterdapatan mata air di suatu wilayah dipengaruhi oleh beberapa faktor, antara lain curah hujan, permeabilitas, topografi, sifat hidrologi lapisan pembawa air, dan struktur geologinya (Todd, 1980). Beberapa faktor pengaruh tersebut menyebabkan karakteristik mata air di suatu wilayah tidak sama, ditinjau dari aspek jumlah, distribusi, sifat hidrologi (kontinuitas dan besar aliran), dan kualitas air.

Wilayah Kabupaten Gunungkidul secara fisiografi dikelompokkan menjadi tiga zona yaitu zona Utara yang disebut kawasan Baturagung, zona Tengah disebut kawasan Ledok Wonosari, dan zona Selatan disebut kawasan karst Gunung Sewu. Satuan fisiografi tersebut dipengaruhi oleh relief, struktur, curah hujan dan geologi, sehingga membentuk satuan bentuk lahan di suatu wilayah yang mempunyai karakteristik tertentu. Perbukitan Baturagung didominasi oleh batuan volkan tua yang telah mengalami tingkat pelapukan lanjut. Basin Wonosari merupakan cekungan dengan topografi datar yang tersusun oleh batuan gamping lagonal (Suprojo, 1988 dalam Widyastuti, 1991). Gunung Sewu merupakan kawasan topografi karst yang mempunyai keunikan secara geomorfologi maupun hidrologi.

Ketiga zona tersebut mempunyai karakteristik lingkungan tertentu dengan potensi dan permasalahannya. Lingkungan fisik ketiga kawasan fisiografi tersebut menentukan keterdapatan mata air, karena masing-masing mempunyai topografi yang khas, materi/batuan penyusun, struktur geologi yang beragam yang kesemuanya mempengaruhi karakteristik mata air. Aspek sosial, lingkungan akan menentukan tingkat adaptif masyarakat dalam menyikapi hidup di lingkungan dengan berbagai gejala atau kejadian yang terkadang sulit untuk dipahami, sehingga manusia dituntut untuk menyesuaikan dan mengambil tindakan sesuai dengan apa yang diterima (Jones dan Gerrad, 1967). Aktivitas yang dilakukan masyarakat secara tidak langsung akan membentuk budaya khas, yang merupakan bentuk penyesuaian diri terhadap lingkungan. 
Perubahan lingkungan menuntut masyarakat yang hidup di dalamnya untuk beradaptasi dengan perubahan tersebut. Tingkat adaptasi tersebut sangat dipengaruhi oleh waktu, intensitas perubahan, daya juang masyarakat dalam menyikapi perubahan. Perubahan tersebut dipengaruhi oleh proses alami maupun non alami. Bentuk penyesuaian diri masyarakat dalam menyikapi perubahan lingkungan terwujud dalam budaya yang khas. Pada umumnya kebudayaan bersifat adaptif dengan kebudayaan manusia, dapat menyesuaikan terhadap kebutuhan fisiologis, lingkungan fisik-geografis, dan lingkungan sosial. Salah satu budaya yang tumbuh di dalam masyarakat adalah kearifan lokal. Kearifan lokal ini terbentuk secara tidak sadar oleh masyarakat dengan melakukan pengelolaan lingkungan dan konservasi yang pada mulanya hanya bertujuan untuk mempertahankan hidupnya. Sebagai contoh, nama-nama mata air mengandung makna sumber air, misalnya tuk, mudal, banyu soca, dan sebagainya. Pemberian tanda-tanda tertentu pada sumber air (mata air) untuk menjaga kelestarian, seperti pagar krapyak, penjaga (juru kunci).

Kabupaten Gunungkidul merupakan wilayahyangidentik dengan permasalahan air atau kekeringan, khususnya di kawasan karst. Secara administratif mencakup 18 kecamatan dan 144 desa. Keterdapatan mata air pada masing-masing fisiografi akan mempunyai karakteristik tertentu. Karakteristik tersebut juga akan mewarnai partisipasi masyarakat sebagai bentuk upaya pelestarian mata air. Mata air yang banyak terdapat di ketiga zona fisiografi merupakan potensi sumberdaya air yang tidak dapat diabaikan. Oleh karena itu, perlu diketahui bentuk partisipasi masyarakat dalam menjaga keberlangsungan fungsi mata air. Tujuan penelitian ini adalah 1) mengidentifikasi karakteristik mata air; 2) mengetahui partisipasi masyarakat dalam upaya pelestarian mata air; 3) menyusun model konservasi berbasis masyarakat.

Air tanah merupakan bagian dari siklus hidrologi, dan didefinisikan sebagai air yang berada di bawah permukaan tanah pada zona jenuh air dengan tekanan hidrostatis sama atau lebih besar dari tekanan udara (Todd, 1980). Keterdapatan air tanah dipengaruhi oleh perkembangan dan sifat-sifat geologi, kondisi batas formasi, iklim, aktivitas manusia, dan kondisi lingkungan (Kashef, 1986). Pemunculan air tanah secara alamiah dapat berupa mata air (spring) atau rembesan (seepage). Mata air atau rembesan selain berasal dari air hujan melalui siklus hidrologi, juga dapat berasal dari air magmatik maupun air fosil (connate water) (Todd, 1980). Karakteristik mata air salah satunya dipengaruhioleh sifat-sifat geologiyang berkaitan dengan lapisan pembawa air (akuifer). Fenomena di daerah penelitian terkait dengan akuifer adalah akuifer media porus pada sisi Utara dan akuifer media rekahan di sisi Selatan daerah penelitian. Menurut Haryono dan Adji (2004), beberapa keunikan yang dijumpai pada mata air karst antara lain, mata air dengan debit sama, bersuhu sama, kesadahan sama dapat dijumpai pada mata air karst yang lain. Mata air karst biasanya mempunyai debit yang besar; karakteristik mata air karst sangat tergantung tingkat karstifikasi (perkembangan karst).

Konservasi secara sederhana diartikan sebagai upaya untuk memelihara apa yang kita miliki (sumberdaya alam). Konservasi menurut Randall (1982) merupakan alokasi sumberdaya antar-waktu yang optimal secara sosial. Secara umum konservasi merupakan pengelolaan sumberdaya secara bijaksana untuk menjamin kesinambungan persediaannya dengan tetap memelihara dan meningkatkan kualitas nilai. Partisipasi aktif dari masyarakat merupakan kunci keberhasilan dari konservasi. Partisipasi merupakan keterlibatan aktif dan bermakna dari masyarakat pada tingkatan-tingkatan yang berbeda di dalam proses pembentukan keputusan untuk menentukan tujuantujuan kemasyarakatan dan pengalokasian sumber-sumber untuk mencapai tujuan yang diinginkan.

Ndraha (1990) mengajukan tiga tolok ukur untuk menilai keberhasilan pembangunan suatu wilayah, yaitu (1) 


\section{SUDARMADJI, SLAMET SUPRAYOGI, M.WIDYASTUTI, RIKA HARINI \& KONSERVASI MATA AIR BERBASIS MASYARAKAT DI UNIT FISIOGRAFI PEGUNUNGAN BATURAGUNG, ...}

sejauhmana kondisi taraf hidup masyarakat dapat diperbaiki; (2) sejauhmana partisipasi masyarakat dalam pembangunan berhasil digerakkan; dan (3) sejauhmana kemampuan masyarakat untuk berkembang secara mandiri berhasil ditumbuhkan. Ciri dan sifaf partisipasi masyarakat antara lain, partisipasi harus bersifat sukarela; berbagai isu atau masalah haruslah disajikan dan dibicarakan secara jelas dan obyektif; serta kesempatan untuk berpartisipasi haruslah mendapat keterangan/informasi yang jelas dan memadai tentang setiap segi/ aspek dari program yang akan didiskusikan (Sastropoetro, 1988).

\section{Materi Penelitian}

Populasi yang menjadi objek dalam penelitian ini adalah mata air beserta karakteristiknya dari aspek kuantitas dan kualitas; serta masyarakat di sekitar mata air yang memanfaatkannya. Identifikasi karakteristk mata air dilakukan dengan sampling secara purposive berdasarkan satuan fisiografi Baturagung, Ledok Wonosari, dan Karst Gunung Sewu. Dalam penentuan responden untuk melakukan wawancara dan depth interview dilakukan dengan sampling secara purposive. Setiap zona akan dipilih secara random sejumlah 30 responden, sehingga dari tiga zone tersebut total sampelnya adalah 90 responden.

Bahan utama dalam penelitian ini adalah sampel air mata air dan hasil kuesioner. Selain itu, beberapa peta tematik dan data yang digunakan untuk mendukung penelitian ini adalah peta fisiografi skala 1:100.00, peta geomorfologi skala 1:100.000, peta geologi skala 1:100.000, peta penggunaan lahan 1: 50.000, dan peta distribusi mata air di Kabupaten Gunungkidul, serta data debit dan kualitas air mata air dari penelitan sebelumnya. Adapun data dalam penelitian ini mencakup data hidrologi mata air dan sosial ekonomi masyarakat. Data hidrologi mata air meliputi data debit dan kualitas air mata air daerah penelitian. Data sosial ekonomi meliputi umur, tingkat pendidikan, pengetahuan, dan penyuluhan, serta tingkat partisipasi masyarakat.

\section{Cara Penelitian}

Alat yang digunakan dalam penelitian ini adalah Global Positioning System (GPS) untuk plotting position mata air, seperangkat alat ukur debit mata air, Electrical Conductivity (EC) meter dan $\mathrm{pH}$ meter, botol sampel air, daftar pertanyaan (kuesioner), software ArcView, dan SPSS.

Data diperoleh secara langsung melalui pengukuran lapangan dan melalui survei instansional. Data primer meliputi debit dan kualitas air dari mata air baik pengukuran langsung lapangan maupun hasil analisa laboratorium, hasil kuesioner. Data sekunder meliputi data lokasi dan debit mata air, data kalitas air dari mata air, peta-peta tematik pendukung, dan data sosial ekonomi.

Pengolahan dan analisis data mata air untuk mengetahui karakteristik mata air dilakukan secara deskriptif kualitatif, sedangkan data sosek untuk mengetahui partisipasi masyarakat dalam konservasi mata air dilakukan secara kuantitatif melalui uji statistik yang disajikan dalam bentuk tabel, grafik, dan peta. Analisisstatistikmenggunakan korelasi rank Spearman untuk mengetahui hubungan dan arah hubungan antar-variabel bebas (independent) yaitu umur, tingkat pendidikan, pengetahuan, dan penyuluhan dengan variabel tergantung (dependent) yaitu tingkat partisipasi masyarakat.

\section{PEMBAHASAN}

Kabupaten Gunungkidul merupakan salah satu kabupaten diantara lima kabupaten/ kota di Propinsi Daerah Istimewa Yogyakarta yang terletak pada sisi Tenggara-Selatan. Daerah penelitian terletak pada koordinat $110^{\circ} 28^{\prime} 12^{\prime \prime}-110^{\circ} 50^{\prime} 24^{\prime \prime}$ BT dan $7^{\circ} 46^{\prime} 48^{\prime \prime}-8^{\circ} 12^{\prime} 36^{\prime \prime}$ LS. Kabupaten Gunungkidul terdiri dari 18 kecamatan dan 144 desa. Kecamatan tersebut adalah adalah Patuk, Nglipar, Gedangsari, Ngawen, Semin, Ponjong, Playen, Wonosari, 
Karangmojo, Semanu, Paliyan, Purwosari, Panggang, Saptosari, Tanjungsari, Tepus, Girisubo, dan Rongkop. Luas keseluruhan wilayah Kabupaten Gunungkidul adalah $1485.36 \mathrm{~km}^{2}$, atau sekitar 46,63\% dari luas total Propinsi Daerah Istimewa Yogyakarta. Wilayah administrasi yang tercakup ke dalam tiga zona fisiografi ditunjukkan pada Tabel 1 dan Gambar 1.

Tabel 1.

Wilayah Kecamatan yang Mencakup Tiga Zona Fisiografi

\begin{tabular}{|l|l|l|}
\hline Fisiografi & Kecamatan & $\begin{array}{l}\text { Jumlah } \\
\text { Desa }\end{array}$ \\
\hline $\begin{array}{l}\text { Perbukitan } \\
\text { Baturagung }\end{array}$ & Patuk & 11 \\
\hline & Nglipar & 7 \\
\hline & Gedangsari & 7 \\
\hline & Ngawen & 6 \\
\hline & Semin & 10 \\
\hline & Ponjong (bag Utara) & 3 \\
\hline $\begin{array}{l}\text { Ledok } \\
\text { Wonosari }\end{array}$ & Playen & 9 \\
\hline & Wonosari & 14 \\
\hline
\end{tabular}

\begin{tabular}{|l|l|l|}
\hline & Karangmojo & 9 \\
\hline & Semanu & 2 \\
\hline & Paliyan & 4 \\
\hline $\begin{array}{l}\text { Perbukitan } \\
\text { Karst } \\
\text { Gunungsewu }\end{array}$ & Purwosari & 5 \\
\hline & Panggang & 6 \\
\hline & Saptosari & 7 \\
\hline & Playen & 2 \\
\hline & Tanjungsari & 5 \\
\hline & Tepus & 5 \\
\hline & Girisubo & 8 \\
\hline & Rongkop & 8 \\
\hline & Semanu & 3 \\
\hline & Ponjong & 6 \\
\hline & Paliyan & 3 \\
\hline
\end{tabular}

\section{Karakteristik Kuantitas dan Kualitas Mata Air Kuantitas Air Mata Air}

Mata air di daerah penelitian sangat potensial, tersebar pada masing-masing zona dengan karakteristiknya. Persebaran mata air pada masing-masing satuan fisiografi tidak terdapat pada setiap desa di masing-masing kecamatan.

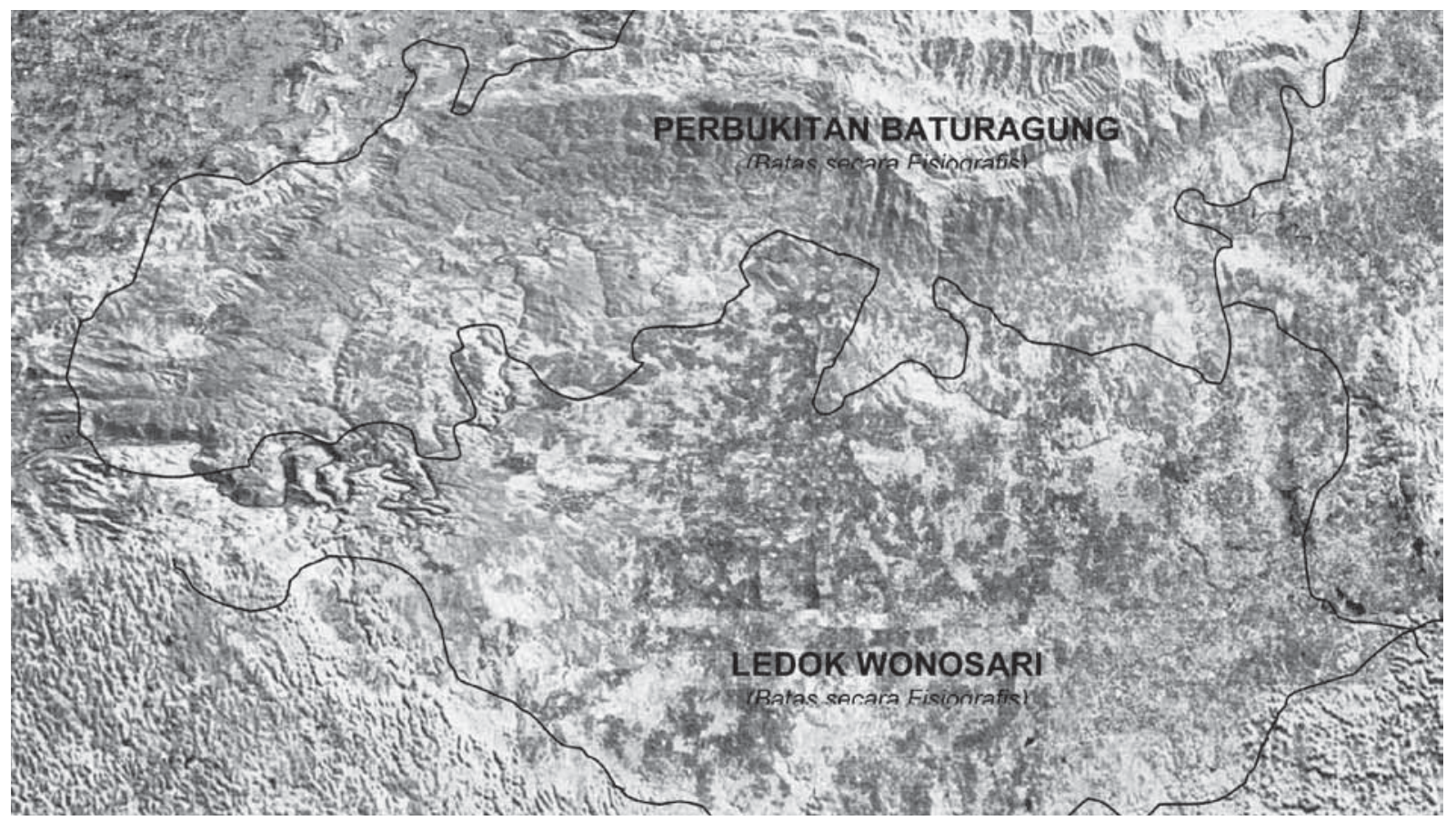

PERBUKITAN KARST GUNUNG SEWU

(Batas secara Fisiografis)

Gambar 1. Kenampakan Satuan Fisiografi di Kabupaten Gunungkidul (Citra Landsat ETM Tahun 2002) 


\section{SUDARMADJI, SLAMET SUPRAYOGI, M.WIDYASTUTI, RIKA HARINI \& KONSERVASI MATA AIR BERBASIS MASYARAKAT DI UNIT FISIOGRAFI PEGUNUNGAN BATURAGUNG, ...}

Setelah gempa pada tahun 2006 lalu, banyak mata air yang bermunculan, dalam hal ini, yang ditambahkan adalah yang sudah terukur debitnya. Perbukitan Baturagung didominasi oleh material breksi volkanik Formasi Nglanggran, breksi tuf Formasi Kebobutak dan Semilir, dan batu pasir tuf Formasi Sambipitu. Atas dasar batuan penyusun tersebut, tidak memungkinkan menyimpan air tanah. Air tanah keluar melalui retakan-retakan atau struktur mayor yang ada berupa rembesan atau mata air, yang ditemukan pada lembah, dan lereng bukit. Basin Wonosari tersusun atas material batu pasir tufaan, napal tufaan, marl, lempung, dan batugamping-aglomerat Formasi Oyo, batugamping dan napal dari Formasi Kepek, dan batugamping terumbu Formasi Wonosari.

Ledok Wonosari merupakan daerah akumulasi air tanah, sehingga sangat potensial. Mat air yang muncul di Ledok Wonosari lebih banyak ditemukan di sisi Utara. Kondisi ini disebabkan konsentrasi air tanah berlimpah di daerah lembah melalui struktur kekar dengan muka air tanah yang dangkal. Sebaliknya di bagian Selatan terjadi penurunan muka air tanah secara tajam ketika berbatasan dengan Perbukitan Karst Gunung Sewu, sehingga jarang ditemukan mata air. Karst Gunungsewu mempunyai kekhususan secara hidrologi maupun geomorfologi. Hal tersebut akan berpengaruh terhadap pemunculan mata air. Banyak mata air yang terdapat di kawasan ini, yang secara umum terbentuk karena adanya penghambat drainase bawah tanah, berupa batuan dasar kedap, sesar atau kontak yang tidak selaras, dan akibat lembah yang terdegradasi.

Mata air yang terdapat di Perbukitan Baturagung tidak tersebar secara merata di setiap desa pada masing-masing kecamatan. Berdasarkan data yang ada, mata air yang tercatat di Kecamatan Ngawen sebanyak 21 titik dan tersebar merata di setiap desa yang masuk dalam wilayah kecamatan tersebut. Kisaran debit mata air yaitu antara
915-567.648 $\mathrm{m}^{3} /$ tahun. Mata air-mata air yang tercatat di Kecamatan Ngawen merupakan data setelah terjadinya gempa dan debitnya terukur, sehingga dapat untuk memperkirakan ketersediaan air mata air. Di Kecamatan Semin terCatat 5 titik, dan di Kecamatan Nglipar tercatat 3 titik.

Ledok Wonosari merupakan tempat akumulasi air tanah, sehingga banyak ditemukan mata air di wilayah ini. Hampir setiap kecamatan yang berada dalam zona ini terdapat mata air dengan jumlah yang banyak. Menurut data yang tercatat, terdapat 78 mata air yang berada di zona ini, dengan rincian; di Kecamatan Karangmojo sebanyak 46, Kecamatan Pojong sebanyak 4, Kecamatan Paliyan sebanyak 3, Kecamatan Ponjong sebanyak 15, dan Kecamatan Wonosari sebanyak10mata air. Berdasarkanhal tersebut, terlihat bahwa Kecamatan Karangmojo merupakan konsentrasi munculnya mata air pada zona ini. Debit aliran mata air berkisar antara 95 - 1.532.650 $\mathrm{m}^{3}$ / tahun. Secara umum sifat aliran mata air menahun artinya ketika musim kemarau tidak terjadi kekeringan, namun demikian terdapat beberapa mata air yang mengalami kekeringan (sifat alirannya sesaat). Pemanfaatan mata air di wilayah ini sebagian besar digunakan untuk air minum, beberapa di antaranya dimanfaatkan untuk irigasi.

Mata air yang berada di kawasan karst cenderung mempunyai debit yang stabil, meskipun terdapat beberapa yang sifatnya sesaat. Dilihat dari penyebarannya tidak semua kecamatan muncul mata air. Di Kecamatan Ponjong terdapat 7 mata air, Kecamatan Semanu dan Paliyan, yaitu (1), Kecamatan Playen (2), Kecamatan Purwosari (27), Kecamatan Panggang (12), Kecamatan Tanjungsari (5), Kecamatan Tepus (15) dan Keamatan Girisubo (12). Dengan demikian sebagian besar penyebaran mata air terdapat di Kecematan Purwosari, dengan debit bervariasi pada kisaran antara 63.072 $63.072 .000 \mathrm{~m}^{3} /$ tahun. 


\section{Kualitas Air Mata air}

Kualitas air mata air dianalisis berdasarkan 13 sampel mata air yang terdiri dari 5 sampel mata air dari Perbukitan Baturagung, 5 sampel dari Perbukitan Karst Gunung Sewu dan 3 sampel mata air dari Ledok Wonosari. Sampel mata air dari Perbukitan Baturagung meliputi Kalisong, Beji, Wonosadi, Garotan, dan Mangli. Mata air dari Ledok Wonosari meliputi Ngembel, Ponjong dan Banyumoto, sedangkan dari Perbukitan Karst Gunungsewu meliputi Banyumeneng, Ngeleng (Petoyan), Sureng, Puring, dan Karangkulon.

Kualitas fisik air mata air dikaji berdasarkan parameter DHL dan kekeruhan. Mata air yang berada pada Ledok Wonosari memiliki nilai DHL rata-rata paling tinggi dibandingkan DHL mata air pada dua zona lainnya, yaitu dengan rentang nilai 405 $479 \mu \mathrm{mhos} / \mathrm{cm}$. Mata air pada Perbukitan Karst Gunung Sewu secara umum memiliki nilai DHL yang paling rendah yaitu berkisar antara 164 - $262 \mu \mathrm{mhos} / \mathrm{cm}$, sedangkan mata air pada Perbukitan Baturagung memiliki nilai DHL lebih tinggi dan relatif bervariasi yaitu $131-406 \mu \mathrm{mhos} / \mathrm{cm}$.

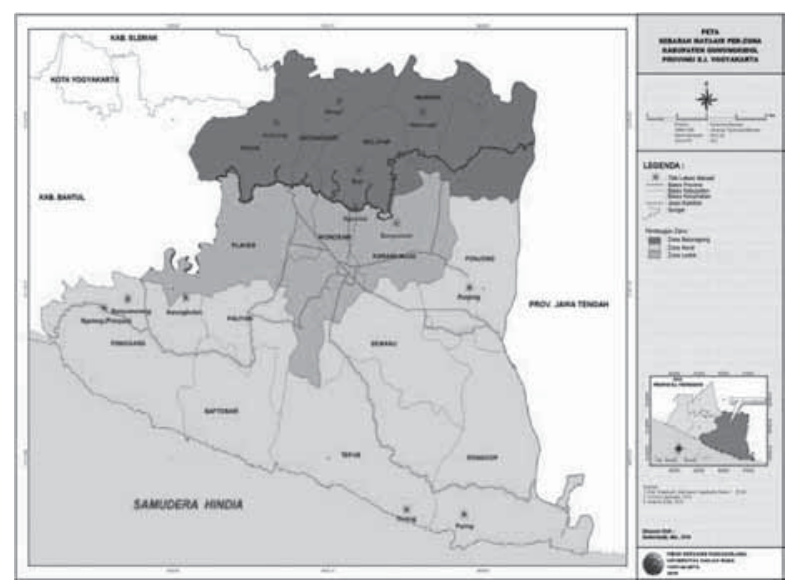

Gambar 2.

Lokasi Mata air yang Disampel

Kekeruhan relatif sama pada hampir seluruh sampel mata air yang diambil. Meski demikian, mata air pada Zona Karst dan
Ledok Wonosari cenderung memiliki nilai kekeruhan lebih tinggi dibandingkan mata air pada Zona Baturagung. Nilai kekeruhan mata air pada Zona Baturagung lebih variatif, yaitu mulai dari 1,66 - 3.54 FTU, Ledok Wonosari 2,45 - 2,64 FTU, sedangkan Karst Gunung Sewu 2,19 - 2,8 FTU.

Kualitas air secara kimia ditinjau dari paremeter, $\mathrm{pH}$, Klorida $\left(\mathrm{Cl}^{-}\right)$, Kebasaan $\left(\mathrm{HCO}_{3}\right)$, Kesadahan $\left(\mathrm{CaCO}_{3}^{-}\right)$, Kalsium $\left(\mathrm{Ca}^{2+}\right)$, dan Magnesium $\left(\mathrm{Mg}^{2+}\right)$, Nitrat $\left(\mathrm{NO}_{3}^{-}\right)$dan Nitrit $\left(\mathrm{NO}_{2}^{-}\right)$, Sulfat $\left(\mathrm{SO}_{4}{ }^{2-}\right)$, Amoniak Bebas $\left(\mathrm{NH}_{3}{ }^{-} \mathrm{N}\right)$ dan Besi Total (Fe). Hasil pengukuran $\mathrm{pH}$ lapangan menunjukkan bahwa seluruh sampel mata air yang diambil memiliki $\mathrm{pH}$ netral-cenderung basa, yaitu 7,05 - 7,89. Tidak terdapat perbedaan $\mathrm{pH}$ yang nyata di antara ketiga zona bentuklahan. Sementara itu, hasil analisis laboratorium menunjukkan bahwa kandungan klorida pada mata air di daerah penelitian berkisar antara $10-38 \mathrm{mg} / 1$.

Konsentrasi $\mathrm{HCO}_{3}{ }^{-}$yang tinggi menunjukkan bahwa mata air di Kabupaten Gunungkidul cenderung merupakan air tipe karbonat. Unsur $\mathrm{HCO}_{3}^{-}$merupakan salah satu penyusun alkalinitas yang utama. Hasil analisis menunjukkan bahwa kadar kebasaan air mata air relatif sama, yaitu di Perbukitan Baturagung 100 - 260 mg/l, Ledok Wonosari 180 - 212 mg/l, sedangkan Perbukitan Karst $184-240 \mathrm{mg} / \mathrm{l}$.

Kesadahan air mata air Perbukitan Baturagung berkisar antara 100 - 252 mg/l, Ledok Wonosari 180 - 212 mg.1 dan Perbukitan Karst Gunung Sewu adalah 184 - 250 mg/1. Kelompok mata air pada Perbukitan Karst Gunung Sewu memiliki nilai kesadahan lebih tinggi dibandingkan kelompok mata air pada kedua zona lainnya. Kesadahan yang tinggi disebabkan batuan penyusun kawasan karst adalah batuan gamping.

Kadar kalsium kelompok mata air pada Perbukitan Karst Gunung Sewu berkisar antara 50 - 126 mg/l, Ledok Wonosari 84 -96 mg/l dan Perbukitan Karst 76 - 108 mg/l. Kelompok mata air pada Perbukitan Karst Gunung Sewu memiliki rata-rata kadar 


\section{SUDARMADJI, SLAMET SUPRAYOGI, M.WIDYASTUTI, RIKA HARINI \& KONSERVASI MATA AIR BERBASIS MASYARAKAT DI UNIT FISIOGRAFI PEGUNUNGAN BATURAGUNG, ...}

kalsium yang lebih tinggi dibanding dengan kedua zona lainnya. Seperti halnya kalsium, kadar magnesium di Perbukitan Karst cenderung lebih tinggi dibanding kedua zona lainnya, yaitu berkisar antara 6,32 - 69,55 mg/l sedangkan Perbukitan Baturagung 0.01 - 27,96 dan Ledok Wonosari 0,01 - 14,53 mg/1. Kalsium dan magnesium pada sampel mata air berasosiasi dengan kandungan $\mathrm{CaCO}_{3}$ (kesadahan), di mana mata air yang memiliki kandungan kalsium dan magnesium tinggi juga cenderung memiliki $\mathrm{CaCO}_{3}{ }^{-}$tinggi. Perbukitan Karst Gunung Sewu cenderung memiliki kesadahan lebih tinggi dibanding zona lainnya, yaitu 292 - 476 mg/l, Perbukitan Baturagung 184 - $260 \mathrm{mg} / \mathrm{l}$ sedangkan Ledok Wonosari 212 - $284 \mathrm{mg} / 1$ sebagai $\mathrm{CaCO}_{3}$

Rata-rata mata air di daerah penelitian memiliki kadar nitrat yang relatif rendah (0- 0,476 mg/l). Ini terjadi karena belum ada faktor pencemar yang berarti di sekitar sumber dan titik pemunculan mata air. Berdasarkan hasil analisis diketahui bahwa seluruh sampel mata air yang diambil mengandung sulfat dalam kadar yang rendah dan normal dalam kisaran sebagai air tawar alami antara 6,2-5,1 mg/1. Kandungan besi total pada keseluruhan sampel termasuk sangat kecil, terutama pada mata air yang berada di Perbukitan Karst Gunung Sewu dan Ledok Wonosari. Kandungan besi total pada mat air di Perbukitan Baturagung relatif lebih tinggi akibat pengaruh batuan penyusun pada zona ini. Kisaran kadar besi total sampel air mata air di daerah penelitian adalah 0,017 - $75 \mathrm{mg} / 1$.

Hasil analisis air menunjukkan bahwa semua sampel mengandung coliform total, bahkan tiga di antaranya sangat tinggi, melebihi $2400 \mathrm{MPN} / 100 \mathrm{ml}$, yaitu mata air Banyumeneng, Banyumoto, dan Ponjong. Mata air Banyumoto dan Ponjong merupakan mata air yang berada di Ledok Wonosari. Zona ini memiliki kepadatan dan aktivitas penduduk lebih tinggi dibandingkan kedua zona lainnya. Berdasarkan Peraturan Menteri Kesehatan Nomor 907/MENKES/SK/
VII/2002, parameter yang diuji masih berada di bawah ambang batas baku mutu yang ditetapkan, yaitu unsur klorida, nitrat, dan sulfat, namun angka coliform total sangat tinggi, melebihi angka $2400 \mathrm{MPN} / 100 \mathrm{ml}$.

\section{Partisipasi Masyarakat dalam Upaya Pelestarian Mata Air}

Saat ini dapat dikatakan cukup sulit untuk mendapatkan air bersih baik secara kuantitas maupun kualitasnya. Hal ini diakibatkan oleh jumlah dan ketersediaannya relatif tetap, tetapi kebutuhan air dipastikan semakin hari semakin meningkat. Partisipasi masyarakat sangat diperlukan untuk menjaga keberadaan dan kelestarian mata air. Pada prinsipnya partisipasi masyarakat dalam pelestarian mata air dapat berlangsung jika masyarakat memiliki pemahan dan kesadaran tentang tujuan dan manfaatnya. Jika masyarakat tidak memahami kemungkinan manfaat yang kurang lebih seimbang dengan pengorbanannya, maka cenderung berpartipasi rendah dalam pelestarian mata air. Demikian juga, jika masyarakat tidak menyadari adanya kepentingan mendesak yang mengharuskan untuk melaksanakan pelestarian dan mempersepsikan bahwa pengorbanan yang harus dikeluarkan relatif besar tidak sesuai dengan manfaatnya, maka akan cenderung berpartisipasi rendah dalam pelestarian mata air. Prinsip-prinsip tersebut melandasi bahasan partisipasi masyarakat dalam pelestarian mata air dalam kaitannya dengan pengetahuan masyarakat sebelumnya.

Upaya pelestarian dengan variabelnya yang terdiri dari upaya tersebut dilakukan perorangan, kelompok swadaya, inisiatif pemerintah dan lainnya yang masih didominasi oleh kelompok swadaya. Tingkat partisipasi dalam pelestarian mata air, sangat berbeda nyata antar wilayah fisiografis. Disamping itu peranserta secara swadaya antar-wilayah tersebut dalam pelestarian mata air (baik perencanaan, pelaksanaan, dan pemanfaatan hasil) merupakan konsekuensi 
perbedaan kondisi fisik daerah dan sosial ekonomi masyarakat. Hambatan fisik daerah seperti (topografi, lahan kering, sarana, dan prasarana fisik wilayah) yang mendominasi daerah-daerah karst dan lajur Baturagung, serta kondisi sosial ekonomi yang tidak sebaik di Ledok Wonosari telah mendorong masyarakat untuk mengatasi kendala dalam rangka pelestarian mata air.

Keberadaan pengelola air bersih mutlak diperlukan karena memiliki kaitan dengan proses sosialisasi kebijakan yang mengatur kebijakan tentang pengelolan air bersih telah jelas disebutkan untuk kegiatan-kegiatan yang boleh dan tidak boleh dilakukan terhadap mata air. Aktivitas ekonomi menyangkut tingkat kesejahteraan masyarakat idealnya terlebih dahulu harus ada pendataan secara menyeluruh terhadap masyarakat yang tinggal di kawasan mata air untuk pekerjaannya terkait dengan pertanian dan masyarakat yang pekerjaannya tidak terkait dengan pertanian (tidak berhubungan secara langsung dengan mata air). Pada semua zona menganggap keberadaan kelompok pengelola air bersih diperlukan demi mewujudkan tata kelola air bersih yang baik.

Masyarakat pada ketiga zona yang ada menganggap bahwa akses lebih besar dalam pengelolaan mata air berada pada semua masyarakat. Peran seluruh masyarakat dalam setiap kegiatan pelestarian mata air dapat memberikan nilai postif bagi keberlangsungan upaya pelestarian mata air, karena masyarakat memiliki pemahaman dan kesadaran tentang tujuan, serta manfaatnya. Prinsip-prinsip tersebut melandasi bahasan partisipasi masyarakat dalam pelestarian mata air dalam kaitannya dengan pengetahuan masyarakat sebelumnya.

Tingkat partisipasi masyarakat dalam berbagai kegiatan pelestarian mata air termasuk kategori tinggi. Meskipun demikian terdapat perbedaan tingkat peran serta masyarakat menurut perbedaan wilayah fisiografis. Perbedaan keikutsertaan dalam setiap kegiatan baik perencanaan, pelaksanaan, dan pemanfaatan hasil mata air sebagai konsekuensi perbedaan kondisi fisik daerah dan sosial ekonomi masyarakat. Variasi tingkat partisipasi masyarakat dalam pelestarian mata air sangat dipengaruhi oleh perbedaan pengetahuan masyarakat tentang mata air tersebut. Semakin tinggi tingkat pengetahuan masyarakat tentang pelaksanaan dan manfaat mata air, maka semakin tinggi tingkat partisipasi dalam pelestarian mata air di setiap wilayah fisiografis yang berbeda. Peta tentang Partisipasi Masyarakat dapat dilihat pada Gambar 3.

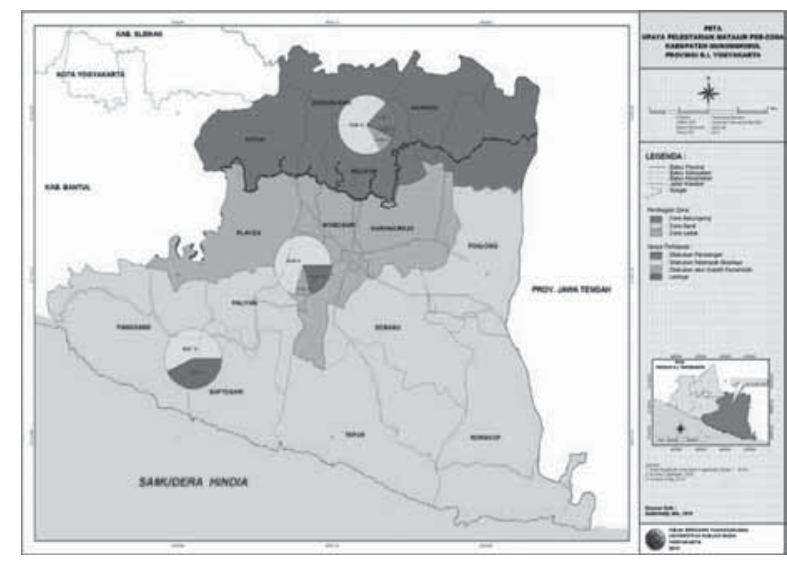

Gambar 3.

Partisipasi Masyarakat dalam Konservasi Mata air

Partisipasi masyarakat dalam kegiatan pelestarian mata air tidak lepas dari pengaruh kondisi sosial ekonomi rumah tangga, lingkungan biofisik, dan budaya. Penelitian yang dilakukan ini menentukan variabel umur kepala keluarga, tingkat pendidikan kepala keluarga, pendapatan kepala keluarga, dan tingkat pengetahuan untuk dilihat hubungannya dengan tingkat partisipasi. Variabel-variabel tersebut dianggap memiliki hubungan secara nyata dengan tingkat partisipasi masyarakat. Selanjutnya dianalisis dengan menggunakan korelasi untuk mengetahui variabel yang memiliki hubungan dengan tingkat partisipasinya yang ditekankan pada hubungan antara variabel sosial ekonomi dengan tingkatan partisipasi masyarakat dalam menjaga kelestarian mata airnya (Tabel 2). 
Tabel 2.

Pengaruh Umur, Tingkat Pendidikan, Pendapatan, dan Pengetahuan terhadap Partisipasi dalam Konservasi Mat a air

\begin{tabular}{|c|c|c|c|c|c|}
\hline \multirow[b]{2}{*}{ No. } & \multirow{2}{*}{\multicolumn{2}{|c|}{ Variabel }} & \multicolumn{3}{|c|}{ Zona } \\
\hline & & & \multirow{2}{*}{$\begin{array}{c}\begin{array}{c}\text { Pegunungan } \\
\text { Baturagung }\end{array} \\
0,164\end{array}$} & \multirow{2}{*}{$\begin{array}{c}\begin{array}{c}\text { Ledok } \\
\text { Wonosari }\end{array} \\
-0,032\end{array}$} & \multirow{2}{*}{$\begin{array}{c}\begin{array}{c}\text { Karst } \\
\text { Gunungsewu }\end{array} \\
0,395^{*}\end{array}$} \\
\hline \multirow[t]{3}{*}{1} & \multirow[t]{3}{*}{ Umur } & Koef. Korelasi & & & \\
\hline & & Sig (2tail) & 0,386 & 0,867 & 0,31 \\
\hline & & $\mathrm{N}$ & 30 & 30 & 30 \\
\hline \multirow[t]{3}{*}{2} & \multirow{3}{*}{$\begin{array}{l}\text { Tingkat } \\
\text { Pendidikan }\end{array}$} & Koef. Korelasi & $0,522^{* *}$ & $0,700^{* *}$ & 0,189 \\
\hline & & Sig, (2tail) & 0,002 & 0,000 & 0,318 \\
\hline & & $\mathrm{N}$ & 30 & 30 & 30 \\
\hline \multirow[t]{3}{*}{3} & \multirow{3}{*}{$\begin{array}{l}\text { Tingkat } \\
\text { Pendapatan }\end{array}$} & Koef. Korelasi & $0,637^{* *}$ & 0,330 & 0,215 \\
\hline & & Sig. (2tail) & 0,000 & 0,075 & 0,253 \\
\hline & & $\mathrm{N}$ & 30 & 30 & 30 \\
\hline \multirow[t]{3}{*}{4} & \multirow[t]{3}{*}{ Pengetahuan } & Koef. Korelasi. & $0,396^{*}$ & 0,204 & 0,199 \\
\hline & & Sig. (2tail) & 0,030 & 0,279 & 0,292 \\
\hline & & $\mathrm{N}$ & 30 & 30 & 30 \\
\hline
\end{tabular}

Pada Perbukitan Baturagung, hubungan antara umur dengan tingkat partisipasinya terjadi secara positif, maksudnya dengan semakin tua umur seseorang maka tingkat partisipasinya akan tinggi walaupun dari besaran angka korelasinya sangat lemah $(0,164)$. Hal senada, terjadi di Perbukitan Karst Gunung Sewu dengan hubungan yang sama (positif) namun hubungan yang terjadi cukup $(0,395)$. Adapun yang memiliki hubungan berkebalikan terjadi di Ledok Wonosari, dimana umur yang muda justru memiliki partisipasi yang tinggi walaupun hubunganya masih sangat lemah.

Hubungan antara pendidikan dengan partisipasi di tiga zona mempunyai nilai positif. Makin tinggi tingkat pendidikannya semakin tinggi pula peran serta masyarakat dalam menjaga dan memelihara mata air. Hubungan yang terjalin di Zona Baturagung antara kedua variabel ini kuat $(0,552)$, nilainya sedikit lebih kecil dari hubungan yang terjalin di Ledok Wonosari yang mencapai 0,700. Di Perbukitan Karst Gunung Sewu, walaupun hubungannya positif namun lemah (hanya $0,189)$.
Tingkat pendapatan memiliki hubungan terutama dalam penentuan keputusan tentang pemanfaatan mata air. Makin tinggi pendapatan rumah tangga maka pelestarian mata airnya semakin tinggi; rumah tangga dengan pendapatan yang tinggi tidak akan terbebani dengan adanya biaya yang harus dikeluarkan sebagai akibat dari upaya pelestarian mata airnya. Berbeda dengan keluarga yang berpendapatan rendah, akan makin terbebani dengan besarnya biaya yang dikeluarkan dalam upaya pelestarian mata air.

Hubungan antara tingkat pendapatan total rumah tangga dengan tingkat partisipasinya adalah postif pada ketiga zona tersebut, namun besaran hubungan kedua variabel tersebut berbeda. Semakin tinggi tingkat pendapatan total rumah tangganya maka akan semakin tinggi tingkat partisipasinya. Apabila di Zona Baturagung memiliki hubungan yang kuat $(0,637)$, maka di dua zona lainnya hubungannya termasuk cukup dan lemah. Ledok Wonosari memiliki nilai 0,330 dan Perbukitan Karst Gunung Sewu lebih pada hubungan yang rendah. 
Hubungan yang terbentuk antara pengetahuan masyarakat tentang mata air dengan tingkat partisipasinya adalah positif. Semakin tinggi tingkat pengetahuan seseorang maka akan semakin tinggi pula tingkat partisipasinya. Pada Zona Baturagung memiliki korelasi yang cukup $(0,395)$, Ledok Wonosari dan Karst Gunungsewu memiliki hubungan yang lemah masing-masing hanya 0,204 dan 0,199. Kenyataan tersebut memberikan gambaran, bahwa semakin tinggi tingkat pengetahuan mengenai mata air, maka semakin tinggi tingkat partisipasinya dalam melestarikan mata air di setiap wilayah fisiografis yang berbeda. Hal ini dapat dijelaskan apabila seseorang memiliki pengetahuan tinggi, maka cenderung tinggi dalam partisipasi pelestarian mata airnya, karena ada harapan manfaat yang diperoleh (jangka panjang) lebih besar dari pada pengorbanan.

Partisipasi masyarakat dalam pelestarian mata air berlangsung secara total (overall), yaitu secara spontan aktif dalam memberikan sumbangan dalam berbagai bentuk dan berperan dalam pengambilan keputusan bersama pada setiap tahap kegiatannya. Partisipasi yang demikian dapat terjadi apabila pengenalan masyarakat terhadap tetangga tinggi, organisasi masyarakat yang diikuti warga menjadi penggerak kegiatan, terdapat chost sharing antara warga, masyarakat harus mendapat akses terbesar sebagai pengambil keputusan melalui mekanisme pengambilan keputusan yang melibatkan semua unsur yang ada yaitu warga, pengurus, dan pemerintah desa, serta terdapat lembaga pengelola air yang independen dan beranggotakan masyarakat setempat.

Peran pemerintah dan tokoh masyarakat melalui pendekatan partisipasi masyarakat dalam menumbuhkan kesediaan masyarakat untuk berpartisipasi ditempuh dengan memobilisasi masyarakat secara intensif dalam setiap kegiatan lingkungan serta menciptakan kegiatan kemasyarakatan yang dapat meningkatkan interaksi masyarakat akan pelestarian mata air. Pendekatan partisipasi masyarakat dalam kegiatan pelestarian merupakan bagian dari pembangunan dari bawah (bottom up planning) dapat dijadikan strategi dalam pengembangan wilayah. Tujuan jangka pendek pendekatan partisipasi masyarakat adalah melaksanakan kegiatan bersama masyarakat untuk memenuhi kebutuhan praktis dan meningkatkan kesejahteraan masyarakat.

\section{Model Konservasi Mata Air Berbasis Masyarakat}

Berdasarkan hasil penelitian, maka model konservasi yang diusulkan adalah penyuluhan kepada masyarakat, pembuatan demplot pecontohan konservasi mata air, pembuatan norma dan peraturan pelaksanaan pengendalian dan larangan kegiatan yang mengancam kelestarian mata air, serta pemantauan dan pengawasan. Penyuluhan dimaksudkan untuk meningkatkan pengetahuan, persepsi maupun partisipasi masyarakat dalam usaha konservasi mata air. Teknik penyuluhan dengan dua cara, penyuluhan secara massal dan penyuluhan kelompok. Demplot percontohan konservasi mata air untuk meningkatkan ketrampilan, dan rasa tanggungjawab masyarakat dalam berpartisipasi secara langsung dalam pelaksanaan konservasi mata air. Materi percontohan tentang pemeliharaan lingkungan di sekitar mata air (menjaga kelestarian tanaman di sekitar mata air, tidak mengusik binatang di sekitar mata air), pengendalian erosi tanah di sekitar mata air, dan memeran-sertakan secara aktif kelompok masyarakat dalam kegiatan konservasi. Percontohan konservasi adalah salah satu sarana teknik penyuluhan, yang disampaikan secara langsung. Pembuatan norma dan peraturan pelaksanaan pengendalian dan larangan kegiatan yang mengancam kelestarian mata air ditujukan untuk menghindari perilaku masyarakat 
setempat maupun dari luar, yang dapat mengancam kerusakan dan kelestarian mata air, misalnya pengendalian penggunaan pupuk dan pestisida, pengendalian tindakan orang-orang yang memasuki wilayah mata air. Aspek penting lain yang perlu dilaksanakan selain penyuluhan masyarakat adalah mengintensifkan pemantauan dan pengawasan langsung kegiatan konservasi mata air di lapangan.

\section{SIMPULAN}

1. Secara kuantitas, debit mata air di Perbukitan Karst Gunung Sewu lebih besar dibanding kedua zona lainnya. Distribusi mata air lebih banyak pada Ledok Wonosari dan Perbukitan Karst Gunung Sewu. Karakteristik mata air di daerah penelitian, dari aspek kualitas air di semua zona fisiografi di daerah penelitian mempunyai kualitas air yang baik, kecuali bakteri coli yang tidak sesuai Baku Mutu Air.

2. Sebagian besar penduduk di Kabupaten Gunungkidul pada ke tiga zona (Perbukitan Baturagung, Ledok Wonosari, dan Perbukitan Karst Gunung Sewu) memiliki pengetahuan yang rendah khususnya hubungan antara musim dengan debit mata air.

3. Partisipasi masyarakat dalam pelestarian mata air lebih banyak dilakukan secara berkelompok melalui kelompok pengguna mata air. Faktor sosial ekonomi masyarakat secara umum, berpengaruh pada pencegahan kerusakan mata air. Semakin tinggi umur, pendidikan, pendapatan dan pengetahuan tentang mata air, maka semakin tinggi tingkat partisipasi masyarakat dalam usaha konservasi mata air.

\section{DAFTAR PUSTAKA}

Fetter, C.W, 1994, Applied Hydrogeology, Prentice Hall Inc, Englewood Cliffs, New Jersey.

Gillieson, D., 1996, Caves: Processes, Development, and Management, Blackwell, Oxford.

Haryono, E. dan Adji, N. T, 2004, Pengantar Geomorfologi dan Hidrologi Karst, Yogyakarta: Kelompok Studi Karst, Fakultas Geografi, Universitas Gadjah Mada.

Jones E.E, and Gerrad. H.B, 1967, Foundation of Social Psichology, Newyork. John Willey \& Sons. Inc.

Kashef, A.I, 1986, Groundwater Engineering, McGraw-Hill Book Company, New York

Notoatmodjo.S,1985, “Beberapa Model Kerangka Analisis Perilaku Kesehatan", dalam Majalah Kesehatan Indonesia XIV (2): 73-76.

Randall, A, 1982, Resources Economic, an Economic Approach to Natural Resources and Environment Policy. Illinois.

Sastropoetro, 1998, Partisipasi, Komunikasi, Persuasi, dan Disiplin dalam Pembangunan

Sukar, 2005, Masih Adakah Kearifan Lokal di Karst Gunungkidul, dalam Makalah Diskusi Lingkungan Hidup Mapala KAPALASASTRA. Yogyakarta: Fakultas Ilmu Budaya UGM.

White, 1988, Geomorphology and Hydrology of Karst Terrain, Oxford: University Press.

Widyastuti, M, 1991, Pengaruh Struktur Kekar terhadap Karakteristik Mata air di Basin Wonosari, Kabupaten Gunungkidul. Skripsi. Yogyakarta: Fakultas Geografi, Universitas Gadjah Mada. 